\title{
Sequence Variation in Two Protein-Coding Genes Correlates with Mycelial Compatibility Groupings in Sclerotium rolfsii
}

\author{
Efrén Remesal, Blanca B. Landa, María del Mar Jiménez-Gasco, and Juan A. Navas-Cortés
}

First, second, and fourth authors: Instituto de Agricultura Sostenible (IAS), Consejo Superior de Investigaciones Científicas (CSIC), Apartado 4084, 14080 Córdoba, Spain; and third author: Department of Plant Pathology, The Pennsylvania State University, 309 Buckhout Laboratory, University Park 16802-4507.

Accepted for publication 3 January 2013.

\begin{abstract}
Remesal, E., Landa, B. B., Jiménez-Gasco, M. M., and Navas-Cortés, J. A. 2013. Sequence variation in two protein-coding genes correlates with mycelial compatibility groupings in Sclerotium rolfsii. Phytopathology 103:479-487.

Populations of Sclerotium rolfsii, the causal organism of Sclerotium root-rot on a wide range of hosts, can be placed into mycelial compatibility groups (MCGs). In this study, we evaluated three different molecular approaches to unequivocally identify each of 12 previously identified MCGs. These included restriction fragment length polymorphism (RFLP) patterns of the internal transcribed spacer (ITS) region of nuclear ribosomal DNA (rDNA) and sequence analysis of two protein-coding genes: translation elongation factor $1 \alpha(\mathrm{EF} 1 \alpha)$ and RNA polymerase II subunit two (RPB2). A collection of 238 single-sclerotial isolates representing 12 MCGs of $S$. rolfsii were obtained from diseased sugar beet plants from Chile, Italy, Portugal, and Spain. ITS-RFLP analysis using

four restriction enzymes (AluI, HpaII, RsaI, and MboI) displayed a low degree of variability among MCGs. Only three different restriction profiles were identified among $S$. rolfsii isolates, with no correlation to MCG or to geographic origin. Based on nucleotide polymorphisms, the RPB2 gene was more variable among MCGs compared with the EF1 $\alpha$ gene. Thus, 10 of 12 MCGs could be characterized utilizing the RPB2 region only, while the EF1 $\alpha$ region resolved 7 MCGs. However, the analysis of combined partial sequences of EF1 $\alpha$ and RPB2 genes allowed discrimination among each of the 12 MCGs. All isolates belonging to the same MCG showed identical nucleotide sequences that differed by at least in one nucleotide from a different MCG. The consistency of our results to identify the MCG of a given $S$. rolfsii isolate using the combined sequences of EF1 $\alpha$ and RPB2 genes was confirmed using blind trials. Our study demonstrates that sequence variation in the protein-coding genes EF1 $\alpha$ and RPB2 may be exploited as a diagnostic tool for MCG typing in $S$. rolfsii as well as to identify previously undescribed MCGs.
\end{abstract}

Sclerotium rolfsii Sacc. is a soilborne plant pathogen that causes diseases on $>500$ plant species worldwide, mostly comprising dicotyledonous but also including some monocotyledonous species (30). The basidial stage of $S$. rolfsii, Athelia rolfsii (Curzi) C. C. Tu \& Kimbr., is not thought to occur commonly in nature, although it has been induced under laboratory conditions (32). In fungal plant pathogens that do not undergo regular sexual reproduction, mycelial compatibility groups (MCGs) provide an indirect measure of genetic variability among isolates, resulting in separate gene pools that may display variation because of the lack of genetic exchange between MCGs (44). Punja and Grogan (33) first described the occurrence of MCGs in $S$. rolfsii populations and, since then, several authors have shown that $S$. rolfsii isolates belonging to the same MCG are genetically closer to each other than to those belonging to a different MCG $(2,8,25)$.

Different approaches based on molecular fingerprinting techniques and sequence analyses have been used to resolve intraspecific variability in several fungal plant pathogens. Daval et al. (11) demonstrated the existence of two main Gaeumannomyces graminis var. tritici groups that were distributed worldwide but that can coexist in the same field. They used DNA sequences of a random amplified polymorphic DNA (RAPD) marker that coded for the gentisate 1,2-dioxygenase-like gene, as well as phylo-

Corresponding author: J. A. Navas-Cortés; E-mail address: j.navas@csic.es

* The $\boldsymbol{e}$-Xtra logo stands for "electronic extra" and indicates that Figure 2 appears in color online.

http://dx.doi.org/10.1094/PHYTO-07-12-0151-R

(C) 2013 The American Phytopathological Society genetic analyses of the internal transcribed spacer (ITS) region of the nuclear ribosomal DNA region (rDNA) (11). In Verticillium dahliae Kleb., Collado-Romero et al. (9) showed that isolates within a vegetative compatibility group (VCG) were more molecularly related based on a significant correlation between VCGs and amplified fragment length polymorphism (AFLP) patterns. Kuninaga et al. (19) found that rDNA-ITS sequence analysis was the most accurate approach to establish the genetic relatedness between anastomosis groups (AGs) in Rhizoctonia solani Kühn.

Similar approaches to those previously reported have been used to analyze populations of $S$. rolfsii. The use of restriction fragment length polymorphism (RFLP) analysis of the rDNA ITS region (ITS-RFLP) allowed Harlton et al. (14) to first distinguish some $S$. rolfsii MCGs at the molecular level from a worldwide collection of isolates. Their results showed that isolates within an MCG displayed identical ITS-RFLP patterns, although certain isolates within an MCG could show distinct ITS-RFLP patterns and certain patterns were also shared among different MCGs. Similar results were obtained by Nalim et al. (25) and Okabe et al. (29), suggesting that some MCGs might have a clonal origin.

RAPD analyses have also been used to assess genetic diversity among S. rolfsii isolates. Punja and Sun (34) could differentiate isolates from a wide host range and geographic origin and belonging to different MCGs by their unique banding patterns. In their work, isolates within a particular MCG, although genetically diverse, shared greater numbers of common bands and clustered together. Only a few members within some MCGs that had identical RAPD patterns were considered to be clonally derived. Okabe and Matsumoto (28) and Almeida et al. (2) also found an association between RAPD groups and some MCGs using $S$. rolfsii isolates from Japan and Brazil, respectively. Cilliers et al. (8) 
identified AFLP analysis as a suitable technique to assess genetic variability between isolates and MCGs of $S$. rolfsii from groundnut sampled in South Africa. Using this technique, these authors effectively differentiated MCGs of $S$. rolfsii from each other but also detected differences between isolates within a single MCG. However, AFLP analyses failed to differentiate between the 12 MCGs from different locations identified by Remesal et al. (35) (E. Remesal, and J. A. Navas-Cortés, unpublished data).

Direct sequencing of the ITS-rDNA region allowed the identification of distinct groups within $S$. rolfsii isolates from Brazil (2), Japan (27), Benin and South Africa (1), and Central Vietnam (20), although no clear correlation between the ITS-based phylogenies and isolate origin or MCG was found.

Introns present in protein-coding genes tend to evolve at a higher rate at the species level than other, more commonly used regions such as the ITS region of the nuclear rDNA. Thus, sequence analyses of these genes have emerged as a reliable tool for high-resolution intraspecific characterization of fungi $(3,13)$. Recently, two single-copy genes, the translation elongation factor $1 \alpha(E F 1 \alpha)$ and the second-largest subunit of the RNA polymerase II (RPB2), have been successfully used in fungi to determine phylogenetic relationships among closely related taxa and for intraspecific phylogenetic inference $(5,21,23,26,37,38,41)$. The EF1 $\alpha$ is a binding protein required for ribosomal protein synthesis in eukaryotes and is the second most abundant protein, with $\leq 2 \%$ of total protein present in active cells (38). The RPB2 encodes the second-largest subunit of the RNA polymerase II, the enzyme that transcribes pre-mRNA $(21,24)$, which possesses 12 highly conserved domains across kingdoms (21).

The identification of a molecular marker that can discriminate among MCGs is of great interest for determining the occurrence, geographical distribution, and changes in $S$. rolfsii populations that might be related to epidemic dynamics. Thus, in the present study, we have assessed the utility of different molecular tools, including ITS-RFLP analysis and sequence analyses of the ITS region, and EF1 $\alpha$ and RPB2 genes, to find diagnostic markers to unequivocally differentiate MCGs in $S$. rolfsii. To achieve this aim, 12 MCGs previously identified from a large collection of $S$. rolfsii isolates from infected sugar beet plants representing different countries with Mediterranean climate (Chile, Italy, Portugal, and Spain) (35) were used. We also explored the possibility of establishing a reference collection of representative isolates of different MCGs that might be of help to plant pathologists in subsequent studies of $S$. rolfsii populations and in epidemiological studies.

\section{MATERIALS AND METHODS}

Fungal isolates and MCGs. In total, 238 mono-sclerotial $S$. rolfsii isolates were used for this study (Table 1). The isolates belong to the 12 MCGs identified by Remesal et al. (35) from a worldwide collection of $S$. rolfsii isolates obtained from 2004 to 2007 from diseased sugar beet crops in different localities in Chile (four localities), Italy (one locality), Portugal (five localities), and Spain (eight localities) (Table 1). In addition, nine $S$. delphinii isolates belonging to a single MCG also sampled from sugar beet fields in southern Italy were included in the study as an outgroup of a closely related taxon. All isolates used in this study are deposited in the culture collection of the Department of Crop Protection, Institute for Sustainable Agriculture (IASCSIC), Cordoba, Spain.

DNA extraction. Mycelia of the fungal isolates were obtained from actively growing colonies on a film of sterile cellophane layered over a plate of potato dextrose agar (PDA; Difco Laboratories, Detroit) and incubated at $25 \pm 1{ }^{\circ} \mathrm{C}$ in the dark for 5 days. Mycelia were harvested and lyophilized, and 20 to $50 \mathrm{mg}$ of lyophilized mycelia were used for DNA extraction using the Fast Prep FP-120 system (MP Biomedicals, Illkirch, France) and the
G-SpinTM IIp Plant Genomic DNA extraction kit (Intron Biotechnology, Korea) according to the manufacturers' instructions. The extracted DNA was checked for quality on a $1 \%$ agarose gel with ethidium bromide staining, quantified using the Quant-iT DNA Broad Range fluorometric assay kit (Molecular Probes, Inc., Leiden, The Netherlands) and a Tecan Safire fluorospectrometer (Tecan Spain, Barcelona, Spain) according to the manufacturers' instructions, and diluted in sterile water to a final concentration of $20 \mathrm{ng} / \mu \mathrm{l}$ for polymerase chain reaction (PCR) assays.

PCR amplifications. The ITS1-5.8S-ITS2 (ITS) region of the rDNA was amplified using universal ITS1 and ITS4 primers (43) in a final reaction volume of $50 \mu$ that consisted of $5 \mu \mathrm{l}$ of $10 \times$ reaction buffer $\left(166 \mathrm{mM}\left[\mathrm{NH}_{4}\right]_{2} \mathrm{SO}_{4}, 670 \mathrm{mM}\right.$ Tris- $\mathrm{HCl}[\mathrm{pH} 8.0$, $25^{\circ} \mathrm{C}$ ], and $0.1 \%$ stabilizer), $1.5 \mathrm{mM} \mathrm{MgCl}_{2}, 200 \mu \mathrm{M}$ each dNTP, $1 \mu \mathrm{M}$ each primer, 2 units of BIOTAQ DNA polymerase (Bioline, Madrid), and $2 \mu$ l of template DNA (40 ng of DNA). The cycling program included an initial denaturization step of $94^{\circ} \mathrm{C}$ for $2 \mathrm{~min}$; followed by 34 cycles of denaturization at $95^{\circ} \mathrm{C}$ for $1 \mathrm{~min}$, annealing at $54^{\circ} \mathrm{C}$ for $1 \mathrm{~min}$, and extension at $72^{\circ} \mathrm{C}$ for $1 \mathrm{~min}$; and a final extension step at $72^{\circ} \mathrm{C}$ for $5 \mathrm{~min}$. The primer pair EF595F and EF1160R was used to amplify a portion of the EF1 $\alpha$ gene targeting exons 4 to 6 and spanning introns 4 and $5(17,42)$. PCR cycle conditions were $94^{\circ} \mathrm{C}$ for $2 \mathrm{~min} ; 34$ cycles of $94^{\circ} \mathrm{C}$ for $1 \mathrm{~min}, 53^{\circ} \mathrm{C}$ for $1 \mathrm{~min}$, and $72^{\circ} \mathrm{C}$ for $1 \mathrm{~min}$; and a final extension step of $72^{\circ} \mathrm{C}$ for $5 \mathrm{~min}$. The primer pair b6.9F and b11R1 was used to amplify a region of the RPB2 gene of $\approx 1,100$ bp spanning exons 4 and 5 (domains 7 to 11$)(21,22)$. PCR cycle conditions were $94^{\circ} \mathrm{C}$ for $2 \mathrm{~min}$; 34 cycles of $94^{\circ} \mathrm{C}$ for $1 \mathrm{~min}, 62^{\circ} \mathrm{C}$ for $1 \mathrm{~min}$, and $72^{\circ} \mathrm{C}$ for $1 \mathrm{~min}$; and a final extension step of $72^{\circ} \mathrm{C}$ for 5 min. PCR amplifications of partial EF1 $\alpha$ and RPB2 genes were carried out in a final reaction volume of $25 \mu \mathrm{l}$ that consisted of $2.5 \mu$ of $10 \times$ reaction buffer, $2 \mathrm{mM} \mathrm{MgCl} 2,200 \mu \mathrm{M}$ each dNTP, $1 \mu \mathrm{M}$ each primer, 1 unit of BIOTAQ DNA polymerase (Bioline), and $1 \mu \mathrm{l}$ of template DNA (20 ng of DNA).

PCR amplifications were performed in a Bio-Rad C1000 thermocycler (Bio-Rad, Madrid). Amplified products were visualized on $1 \%$ agarose gels in $1 \times$ Tris-acetate-EDTA (TAE) buffer with ethidium bromide staining, and the Gene-ruler DNA ladder mix (MBI Fermentas, St. Leon-Rot, Germany) was used as molecular weight ladder.

ITS-RFLP analysis. The PCR products resulting from amplifications of the ITS region of the rDNA were digested with AluI, RsaI, HpaII, and MboI (MBI Fermentas) in a final reaction volume of $10 \mu \mathrm{l}$ that contained $5 \mu \mathrm{l}$ of PCR product, $1 \mu \mathrm{l}$ of $10 \times$ buffer, and $5 \mathrm{U}$ of each enzyme; enzymes were incubated independently at $37^{\circ} \mathrm{C}$ for $3 \mathrm{~h}$. Enzyme-digested PCR products were size fractioned on 3\% ReadyAgarose Wide-Mini Gels stained with ethidium bromide (Bio-Rad) in 1× TAE Buffer for $3 \mathrm{~h}$ at 80 V. The Amplisize DNA ladder (Bio-Rad) was included in order to normalize the banding pattern of ITS-RFLP profiles. Then, images were converted, normalized and combined using Bionumerics 6.1 software (Applied Maths, Sint-Martens-Latem, Belgium).

DNA sequencing. The ITS and partial EF1 $\alpha$ and RPB2 gene PCR products were purified using an ULTRAPrep PCR purification kit (AHN Biotechnologie, Nordhausen, Germany) according to the manufacturer's instructions, quantified with a NanoDrop ND-1000 spectrophotometer (NanoDrop Technologies, Wilmington, DE), and used for direct DNA sequencing in a terminator cycle sequencing ready reaction kit (BigDye; PerkinElmer, Applied Biosystems, UK) according to the manufacturers' instructions on a DNA multicapillary sequencer (Model 3100 genetic analyzer; Applied Biosystems) at STABVIDA sequencing facilities (Monte da Caparica, Portugal). Purified products were sequenced in both directions using the same primers that were used for PCR amplifications. Direct sequencing of RPB2 PCR products with b6.9F primer did not provide readable sequences; consequently, a forward primer bSr_1F (5'-CGCCATGGGTAAA 
CAAGCTA-3') was designed using PRIMER3 software v.0.4.0 (http://frodo.wi.mit.edu/primer3/) and used for sequencing instead.

Data analyses. The ITS-RFLP patterns were analyzed with Bionumerics software v.6.1. Normalized view and band searching were performed creating a reference system with the Amplisize DNA ladder (50 to 2,000 bp) lanes that allowed estimating sizes of the digested bands. Bands of $<50 \mathrm{bp}$ were not considered for further analyses. A set of 34 isolates representing all possible combinations of MCG-locality that displayed identical ITS-RFLP profiles was selected and a band-matching algorithm (bandmatching optimization of $0.9 \%$ and a tolerance limit of $1.1 \%$ ) was used to calculate pairwise similarity matrices using the Dice coefficient. Cluster analysis of similarity matrices was performed by the unweighted pair group method using arithmetic averages (UPGMA). Trees were bootstrapped with 1,000 replicates to assess branch support.

Sequence traces for ITS and partial EF1 $\alpha$ and RPB2 genes were visualized and edited with BioNumerics software v.6.1 using default parameters. Initially, multiple alignments with all isolate sequences for each gene region were performed using fast algorithm and default parameters. After this, the 34 representative isolates from each MCG-locality combination with identical nucleotide sequences were selected for subsequent distance analysis and clustering based on the neighbor-joining method

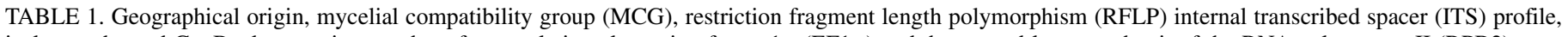

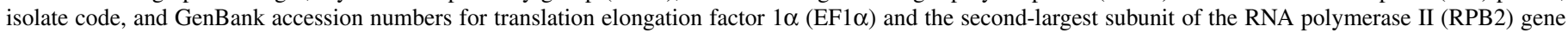

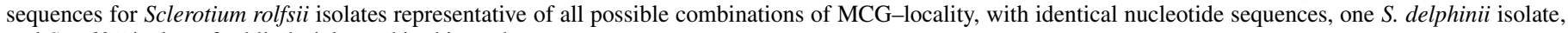
and $S$. rolfsii isolates for blind trials used in this study

\begin{tabular}{|c|c|c|c|c|c|c|c|}
\hline \multicolumn{2}{|l|}{ Geographical origin } & \multirow[b]{2}{*}{$\mathrm{MCG}^{\mathrm{a}}$} & \multirow[b]{2}{*}{$N^{\mathrm{b}}$} & \multirow[b]{2}{*}{ ITS-RFLP ${ }^{c}$} & \multicolumn{3}{|c|}{ Representative isolates (MCG-locality) ${ }^{\mathrm{d}}$} \\
\hline Country, province & Locality & & & & Code & EF1 $\alpha$ & RPB2 \\
\hline \multicolumn{8}{|l|}{ S. rolfsii } \\
\hline \multicolumn{8}{|l|}{ Chile } \\
\hline VI & Colchagua & vii & 1 & III & $\mathrm{Sr}-1$ & JF267805 & JF267840 \\
\hline \multirow[t]{4}{*}{ VII } & Curicó & iii & 2 & I & Sr-2 & JF267806 & JF267841 \\
\hline & Linares & viii & 3 & I & Sr-5 & JF267809 & JF267844 \\
\hline & Linares & ix & 1 & I & $\mathrm{Sr}-7$ & JF267795 & JF267830 \\
\hline & Linares & xii & 4 & II & Sr-10 & JF267808 & JF267843 \\
\hline \multicolumn{8}{|l|}{ VIII } \\
\hline & Nuble & iii & 1 & I & Sr-12 & JF267794 & JF267829 \\
\hline & Nuble & ix & 9 & I & $\mathrm{Sr}-21$ & JF267810 & JF267845 \\
\hline & Ñuble & $\mathrm{x}$ & 1 & I & $\mathrm{Sr}-22$ & JF267807 & JF267842 \\
\hline \multicolumn{8}{|l|}{ Spain } \\
\hline \multirow[t]{5}{*}{ Cádiz } & Arcos Fra. & $\mathrm{i}$ & 20 & I & Sr-24 & JF267823 & JF267859 \\
\hline & Jerez Fra. & $\mathrm{i}$ & 16 & I & Sr-112 & JF267818 & JF267856 \\
\hline & Jerez Fra. & iii & 4 & I & Sr-119 & JF267819 & JF267855 \\
\hline & Vejer Fra. & $\mathrm{i}$ & 12 & I & Sr-136 & JF267824 & JF267860 \\
\hline & Vejer Fra. & $\mathrm{v}$ & 10 & II & Sr- 155 & JF267825 & JF267861 \\
\hline \multicolumn{8}{|l|}{ Córdoba } \\
\hline & Fuente Palmera & $\mathrm{i}$ & 15 & I & Sr-182 & JF267812 & JF267847 \\
\hline & Posadas & $\mathrm{i}$ & 4 & I & Sr-194 & JF267803 & JF267838 \\
\hline & Posadas & ii & 15 & II & Sr-203 & JF267802 & JF267837 \\
\hline & Posadas & iii & 7 & I & $\mathrm{Sr}-222$ & JF267809 & JF267839 \\
\hline & Paterna Campo & $\mathrm{i}$ & 17 & I & Sr-243 & JF267816 & JF267851 \\
\hline & Paterna Campo & $\mathrm{xi}$ & 2 & I & Sr-286 & JF267815 & JF267850 \\
\hline \multirow[t]{4}{*}{ Seville } & Lebrija & $\mathrm{i}$ & 2 & I & $\mathrm{Sr}-289$ & JF267822 & JF267858 \\
\hline & Lebrija & iii & 17 & I & $\mathrm{Sr}-296$ & JF267821 & JF267857 \\
\hline & Los Palacios & $\mathrm{i}$ & 19 & I & $\mathrm{Sr}-324$ & JF267820 & JF267854 \\
\hline & Los Palacios & ii & 1 & II & Sr-395 & JF267798 & JF267833 \\
\hline \multicolumn{8}{|l|}{ Italy } \\
\hline Bari & Bari & iv & 1 & I & Sr-396 & JF267817 & JF267852 \\
\hline \multicolumn{8}{|l|}{ Portugal } \\
\hline \multirow[t]{10}{*}{ Lisbon } & Vila Franca Xira & $\mathrm{i}$ & 1 & I & Sr-407 & JF267797 & JF267832 \\
\hline & Vila Franca Xira & iii & 6 & I & Sr-413 & JF267814 & JF267848 \\
\hline & Vila Franca Xira & $\mathrm{V}$ & 2 & II & Sr-414 & JF267813 & JF267849 \\
\hline & Vila Franca Xira & $\mathrm{v}$ & 6 & II & Sr-416 & JF267826 & JF267862 \\
\hline & Vila Franca Xira & vi & 6 & I & Sr-427 & JF267827 & JF267863 \\
\hline & Avis & iii & 12 & I & $\mathrm{Sr}-441$ & JF267801 & JF267836 \\
\hline & Benavila & iii & 7 & I & $\mathrm{Sr}-444$ & JF267800 & JF267835 \\
\hline & Elvas & iii & 8 & I & Sr-457 & JF267811 & JF267846 \\
\hline & Coruche & iii & 6 & I & Sr-465 & JF267799 & JF267834 \\
\hline & Coruche & vi & 1 & I & Sr-468 & JF267796 & JF267831 \\
\hline \multicolumn{8}{|l|}{ S. delphinii } \\
\hline \multicolumn{8}{|l|}{ Italy } \\
\hline Bari & Bari & $\ldots$ & 9 & IV & Sd-405 & JF267828 & JF267853 \\
\hline \multicolumn{8}{|l|}{ S. rolfsii } \\
\hline Morocco & Unknown & $\mathrm{i}$ & 10 & $\ldots$ & Sr-469 & JN790643 & JN490640 \\
\hline Chile & Unknown & ix & 5 & $\ldots$ & $\mathrm{Sr}-470$ & JN790644 & JN790641 \\
\hline India & Unknown & xiiii $^{f}$ & 10 & $\ldots$ & $\mathrm{Sr}-471$ & JN790645 & JN790642 \\
\hline
\end{tabular}

a MCGs were determined by isolate pairing in growth media in a previous study (35).

b Number of isolates.

c Profile: ITS-RFLP patterns generated by MboI, AluI, HpaII, and RsaI restriction enzymes.

d Isolate codes (Code) and GenBank accession numbers for EF1 $\alpha$ and RPB2.

e Isolates of Sclerotium rolfsii used in blind trials.

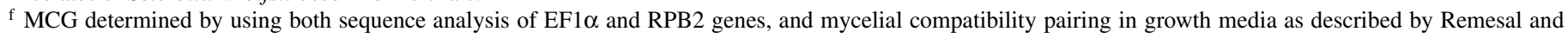
Navas-Cortés (36). 
(40). The phylograms were bootstrapped 1,000 times to assess the degree of support for the phylogenetic branching indicated by the optimal trees. All analyses were performed with BioNumerics software v.6.1. Trees were rooted by using $S$. delphinii sequences data available in the GenBank database (accession numbers JF267828 [EF1 $\alpha]$ and JF267853 [RPB2]) as outgroup. Sequences determined in this study for $S$. rolfsii isolates representative of all MCG-locality combinations were submitted to GenBank. Accession numbers are listed in Table 1. Aligned matrices of EF1 $\alpha$ and RPB2 genes sequences and resulting dendrograms were deposited in TreeBase (submission numbers S12971 [EF1 $\alpha$ ] and S12973 [RPB2]).

Blind trials. To determine the reliability of the protein-coding gene sequences for identification of MCGs of $S$. rolfsii, 20 new isolates of $S$. rolfsii of unknown MCG were used in blind trials. These isolates were obtained from Sclerotium root rot-affected sugar beet plants growing in different commercial crops from two new additional countries (India and Morocco) as well as five new isolates from Chile. Each isolate was assigned to an MCG based on simultaneous sequence analysis and mycelial compatibility tests in growth medium pairings, as described by Remesal and Navas-Cortés (36). Nucleotide sequences for representative isolates from Chile, Morocco, and India used in those blind trials were submitted to GenBank. Accession numbers are listed in Table 1.

\section{RESULTS}

ITS-RFLP analysis. A single band of $\approx 695$ bp was obtained from ITS amplifications for all $S$. rolfsii isolates. The PCR products resulting from the ITS amplifications digested with each of the four restriction enzymes resulted in various restriction profiles, with sizes shown in Figure 1.

For $S$. rolfsii isolates, one restriction pattern each was obtained for $A l u \mathrm{I}$ (A1), HpaII (H1), and RsaI (R1) and three restriction patterns for MboI (M1, M2, and M3) (Fig. 1). Combining restriction patterns generated by the four enzymes, the 12 MCGs were split into three ITS-RFLP groups based on the MboI patterns that were highly supported by the UPGMA analysis with $100 \%$ bootstraps values. ITS-RFLP group I comprised A1, H1, R1, and M1 patterns; ITS-RFLP group II comprised A1, H1, R1, and M2 patterns; and ITS-RFLP group III included A1, H1, R1, and M3 patterns (Table 1; Fig. 1). ITS-RFLP could not differentiate among MCGs. In fact, although all isolates belonging to the same MCG had an identical MboI pattern, the same pattern was also observed for isolates belonging to different MCGs (Table 1; Fig.

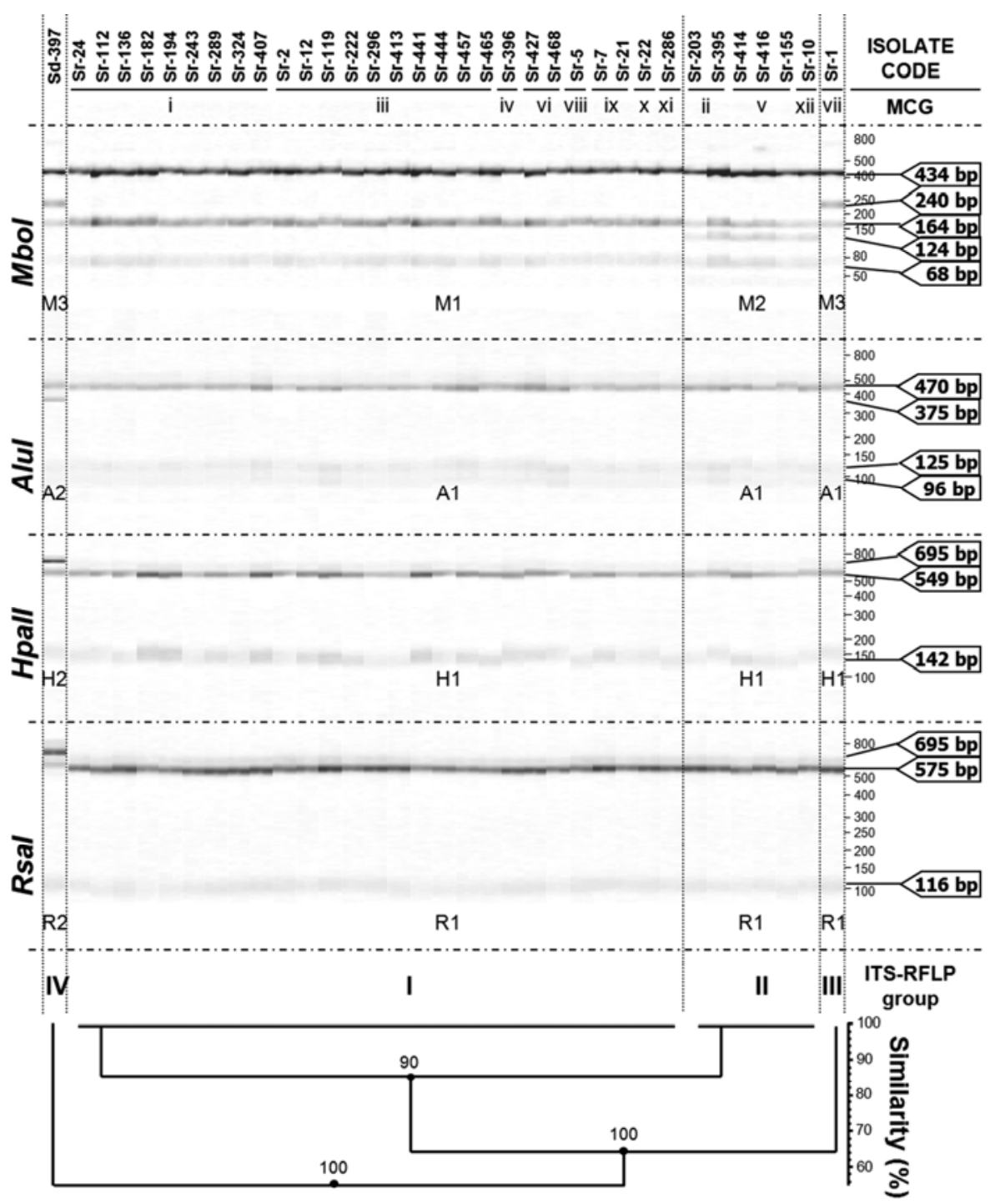

Fig. 1. Dendrogram inferred from unweighted pair group method using arithmetic averages with the Dice coefficient (band-matching tolerance $=1.1 \%$; optimization $=0.9 \%$ ) and band sizes of combined restriction fragment length polymorphism (RFLP) patterns generated by MboI, AluI, HpaII, and RsaI restriction enzymes for each internal transcribed spacer (ITS)-RFLP pattern. Mycelial compatibility group (MCG) and ITS-RFLP group are indicated for each Sclerotium rolfsii and $S$. delphinii isolate. Bootstraps values are indicated in each node. 
1). However, for $S$. delphinii isolates, three banding patterns clearly different from those obtained for $S$. rolfsii isolates were identified for AluI (A2), HpaII (H2), and RsaI (R2) whereas, for $M b o$ I, they shared the M3 pattern with $S$. rolfsii isolates. This allowed the establishment of an additional ITS-RFLP group IV that comprised all $S$. delphinii isolates. The estimated sizes of each band within each pattern were as follows: A2, four fragments of $470,375,125$, and $96 \mathrm{bp} ; \mathrm{H} 2$, three fragments of 695,549 , and $142 \mathrm{bp}$; and R2, three fragments of 695,575 , and $116 \mathrm{bp}$.

Sequence analysis of ITS and of partial EF1 $\alpha$ and RPB2 genes. Nucleotide sequences from the ITS1-5.8S-ITS2 region of the $238 \mathrm{~S}$. rolfsii isolates in the study were obtained; however, they could not be included in phylogenetic analyses because, for isolates belonging to 7 of the 12 MCGs, the sequence traces showed overlapping fluorograms after a certain position, indicating the existence of multiple and different copies of this region per isolate (data not shown).

A fragment of $540 \mathrm{bp}$ was amplified for the EF1 $\alpha$ gene. $\mathrm{Nu}-$ cleotide sequence alignments among all isolates and MCGs showed that the isolates of $S$. rolfsii were grouped according to the MCG but not to their geographic origin. For this reason, to identify nucleotide positions differentiating MCGs in S. rolfsii, a representative set of 34 isolates of each MCG-locality combination with identical nucleotide sequence was selected for subsequent analysis. The variability found in EF1 $\alpha$ sequences was due to differences in seven nucleotide positions, with two of them showing a single transversion or transition each and five of them indicating the presence of at least two EF1 $\alpha$ alleles (ambiguities in the trace of the chromatograms), with four transitions and one transversion (Fig. 2). EF1 $\alpha$ sequences showed similarity percentages of 99.1 to $100 \%$ (data not shown). EF1 $\alpha$ sequences allowed discrimination of MCGs ii, iv, v, viii, $x$, xi, and xii from each other while MCGs i and vii and MCGs iii, vi, and ix, respectively, shared identical EF1 $\alpha$ sequence (Fig. 2).

A 1,167-bp amplicon was amplified from the RPB2 gene. Sequence alignment of all isolates showed no correlation between sequence type and geographic origin of the isolates but isolates were grouped according to their MCG. As described above, a set of 34 isolates representing all possible MCG-locality combinations with identical nucleotide sequence was selected for subsequent analysis to identify nucleotide positions differentiating MCGs (Fig. 2). Thus, MCGs iii and viii shared the same RPB2 sequence while each of the remaining MCGs (MCGs i, ii, iv, v, vi, vii, ix, x, xi, and xii) showed unique sequences that allowed differentiation of each $S$. rolfsii MCG from the others (Fig. 2). The variability found among RPB2 sequences for each MCG was due to differences in 29 nucleotide positions, with all of them showing ambiguities in the trace of the chromatograms that indicated the presence of at least two RPB2 copies, from which only one was a transversion, and 28 transitions (Fig. 2). Values of similarity for RPB2 sequences were 97.6 to $100 \%$ (data not shown).

Distance analysis of EF1 $\alpha$ sequences grouped MCGs into four main clusters (Fig. 3A). MCG x, comprising one isolate from Chile (Table 1), clustered independently (cluster A) from the remaining MCGs (Fig. 3A). MCGs ii, iv, viii, and xii grouped together in cluster B (62\% bootstrap support) (Fig. 3A). Those MCGs were isolated from two localities in southern Spain (MCG ii), one locality in Italy (MCG iv), and one locality in Chile (MCGs viii and xii) (Table 1). Cluster C grouped MCGs i, v, vii, and xi (63\% bootstrap support) (Fig. 3A). MCGs i, v, and xi were only present in certain localities of southern Spain and Portugal and, interestingly, MCGs $\mathrm{i}$ and $\mathrm{v}$ were present in the same field plot sampled at Vejer de la Fra., Spain and Vila Franca Xira, Portugal whereas MCG vii was only identified at one locality of Chile (Table 1). MCGs iii, vi, and ix (cluster D) shared the same EF1 $\alpha$ sequence (Fig. 3A) and included isolates sampled at different localities of Chile, Spain, and Portugal (Table 1).

Distance analysis of RPB2 sequences grouped all MCGs into four main clusters (Fig. 3B). MCGs iv, xi, and vii clustered separately (100\% bootstrap support; cluster A) from the remaining MCGs (Fig. 3B). Those MCGs comprised a total of four isolates and showed a local geographic distribution. Moreover, they were identified in three distant localities in Italy, Spain, and Chile, respectively (Table 1). MCGs ii, xii, and v grouped together in cluster B ( $72 \%$ bootstrap support) that comprised isolates sampled at localities of southern Spain (Posadas, Vejer de la Fra, and Los Palacios), Chile (Linares), and Portugal (Vila Franca Xira), respectively (Table 1). Cluster C (not well supported, bootstrap support $<50 \%$ ) was formed by MCGs i, vi, and ix that were identified at localities of Spain, Portugal, and Chile, respectively (Fig. 3B; Table 1). Finally, MCG iii, the most prevalent MCG in the study, and viii, identified at one locality of Chile (Table 1), that shared the same RPB2 sequences, grouped

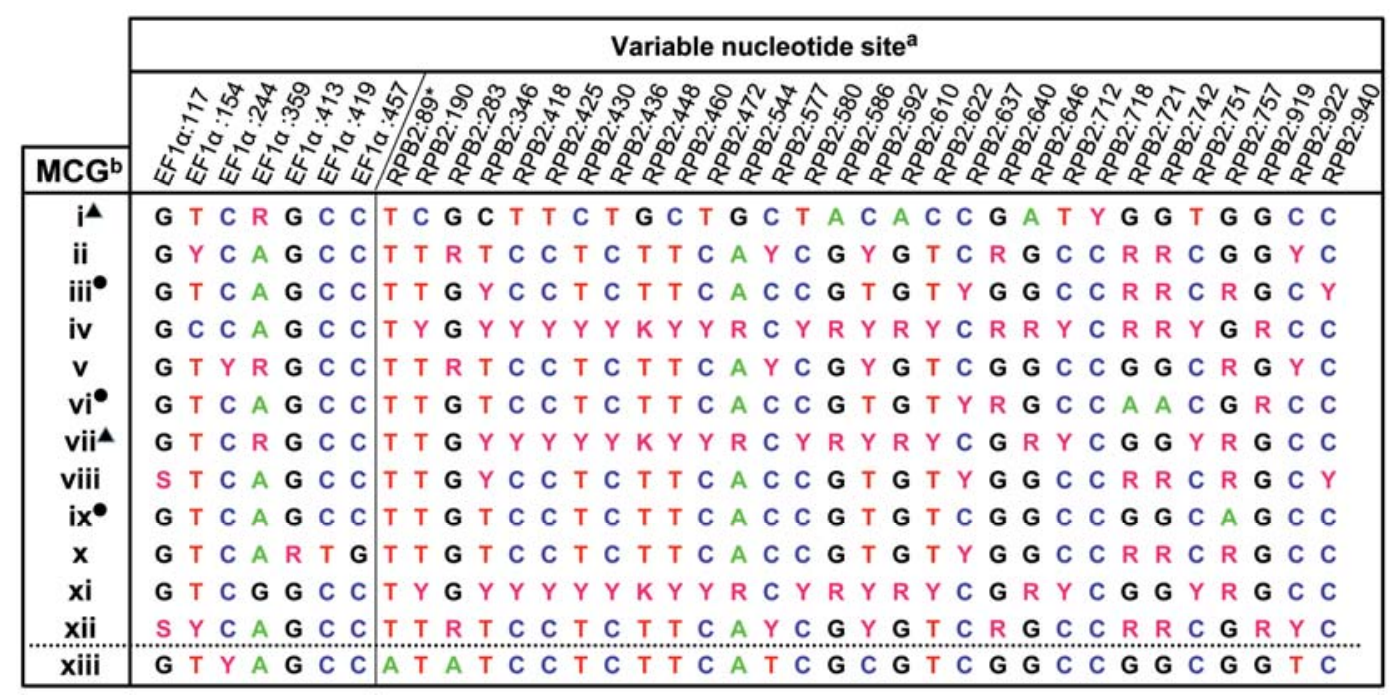

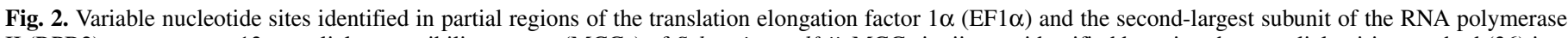

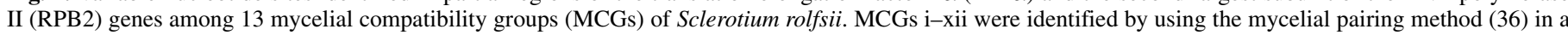

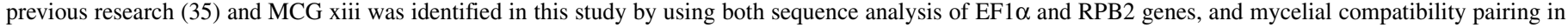

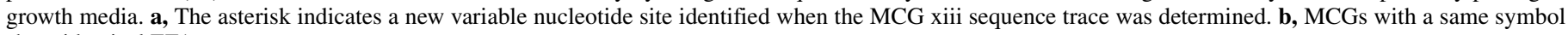
share identical EF1 $\alpha$ sequence. 
with MCG x into cluster D (91\% bootstrap support; Fig. 3B). Interestingly, MCG $\mathrm{x}$ was present in the same field plot sampled at Chillan in Chile (Table 1).

Combined alignments of EF1 $\alpha$ and RPB2 genes allowed discrimination of all $12 \mathrm{~S}$. rolfsii MCGs used in the study (Fig. 2). Thus, those MCGs that could not be resolved by a single gene sequence (Figs. 3A and B) (i.e., MCGs i and vii, and MCGs iii, vi, and i, for the EF1 $\alpha$ gene; and MCGs iii and viii for the RPB2 gene) were now unequivocally distinguished (Fig. 2). A single nucleotide difference was enough to resolve MCGs iii from viii (EF1 $\alpha$ : 117) (Fig. 2), two differences were needed to differentiate between MCGs ii and xii (RPB2: 919, and EF1 $\alpha$ : 117) (Fig. 2) or between MCGs vii and xi (RPB2: 190 and EF1 $\alpha$ : 359) (Fig. 2), and at least five differences were needed to discriminate among the remaining MCGs (i.e., among MCGs viii and x) (RPB2: 940 and $\mathrm{EF} 1 \alpha$ : 117, 413, 419, and 457) (Fig. 2), resulting in a complete characterization of the $12 \mathrm{~S}$. rolfsii MCGs. Five MCGs (i.e., iii, iv, vi, ix, and xi) showed no ambiguities in the EF1 $\alpha$ gene and, from those, only MCG ix showed no ambiguities in the RPB2 gene; the remaining MCGs showed 1 to 2 ambiguities in the EF1 $\alpha$ gene and 1 to 22 ambiguities in the RPB2 gene.

Blind trials. The consistency of the combined use of the EF1 $\alpha$ and RPB2 sequences to assign $S$. rolfsii isolates into an MCG was further tested and demonstrated in a blind trial in which a given $S$. rolfsii isolate was assigned to an MCG by using two approaches: sequence analysis and mycelial compatibility pairing. For this purpose, we tested 25 previously uncharacterized $S$. rolfsii isolates obtained from infected sugar beet in Chile ( 5 isolates), India (10 isolates), and Morocco (10 isolates). Results indicated that all tested isolates from Chile and Morocco were included in MCGs ix and i, respectively, based on the $100 \%$ matching with EF1 $\alpha$ and RPB2 sequences from those MCGs, as well as by the mycelial compatibility reaction with tester isolates from the same MCGs. Conversely, the isolates from India could not be assigned to any of the 12 MCGs previously defined because their nucleotide sequences for EF1 $\alpha$ and RPB2 genes did not match any of those obtained for the 12 MCGs included in the study. As expected, none of the MCG tester isolates showed compatible mycelial reactions with those isolates; therefore, they were assigned to a new MCG named MCG xiii (Table 1; Fig. 3). Interestingly, this MCG xiii showed one ambiguity in the EF1 $\alpha$ gene but not in the RPB2 gene, and a new nucleotide position in the RPB2 sequence gene at position 89 from the previous 29 identified served to differentiate among MCGs.

\section{DISCUSSION}

The identification of MCGs within $S$. rolfsii populations has been addressed by different authors since Punja and Grogan (33) first described MCG occurrence in this pathogen. This method-

\section{A EF1a}

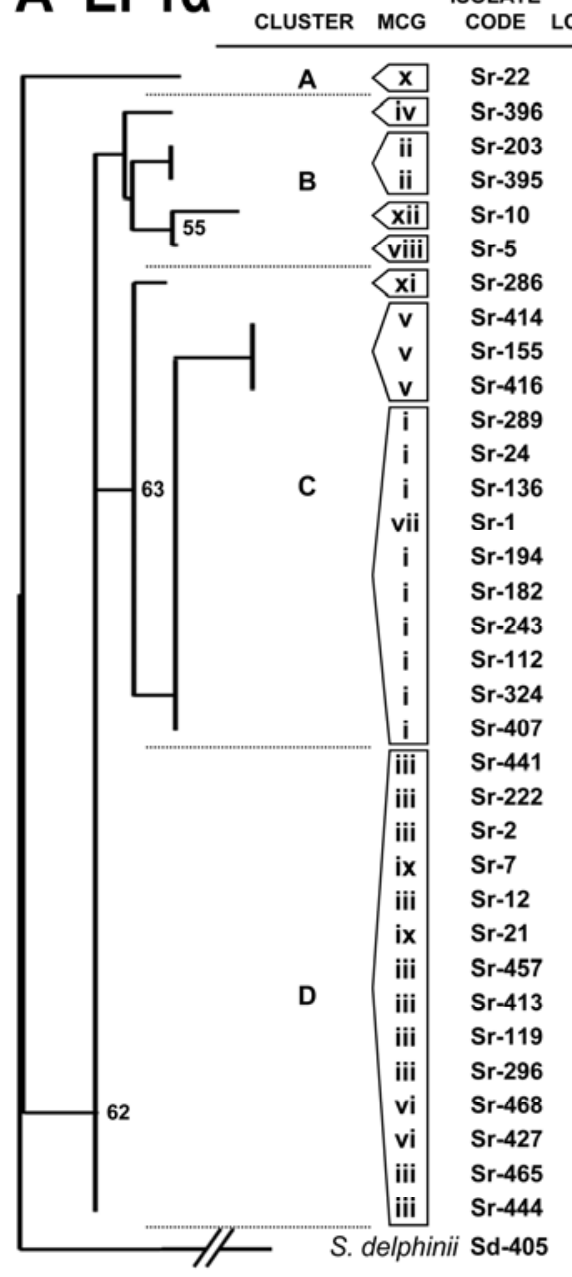

B RPB2

ISOLATE

CLUSTER MCG CODE LOCALITY COUNTRY

\begin{tabular}{|c|c|}
\hline $\mathrm{CHI}$ & $\mathrm{CHL}$ \\
\hline BAR & ITA \\
\hline POS & SPA \\
\hline LPL & SPA \\
\hline LIN & $\mathrm{CHL}$ \\
\hline LIN & $\mathrm{CHL}$ \\
\hline PCM & SPA \\
\hline VFX & PRT \\
\hline VEJ & SPA \\
\hline VFX & PRT \\
\hline LEB & SPA \\
\hline ARC & SPA \\
\hline VEJ & SPA \\
\hline COL & $\mathrm{CHL}$ \\
\hline POS & SPA \\
\hline FPL & SPA \\
\hline PCM & SPA \\
\hline JER & SPA \\
\hline LPL & SPA \\
\hline VFX & PRT \\
\hline AVS & PRT \\
\hline POS & SPA \\
\hline CUR & $\mathrm{CHL}$ \\
\hline LIN & $\mathrm{CHL}$ \\
\hline $\mathrm{CHI}$ & $\mathrm{CHL}$ \\
\hline $\mathrm{CHI}$ & $\mathrm{CHL}$ \\
\hline ELV & PRT \\
\hline VFX & PRT \\
\hline JER & SPA \\
\hline LEB & SPA \\
\hline COR & PRT \\
\hline VFX & PRT \\
\hline COR & PRT \\
\hline BEN & PRT \\
\hline BAR & ITA \\
\hline
\end{tabular}

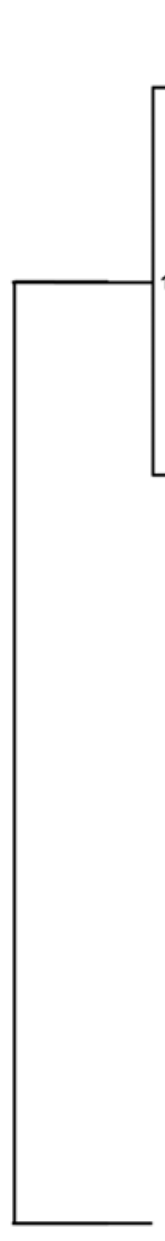

CODE

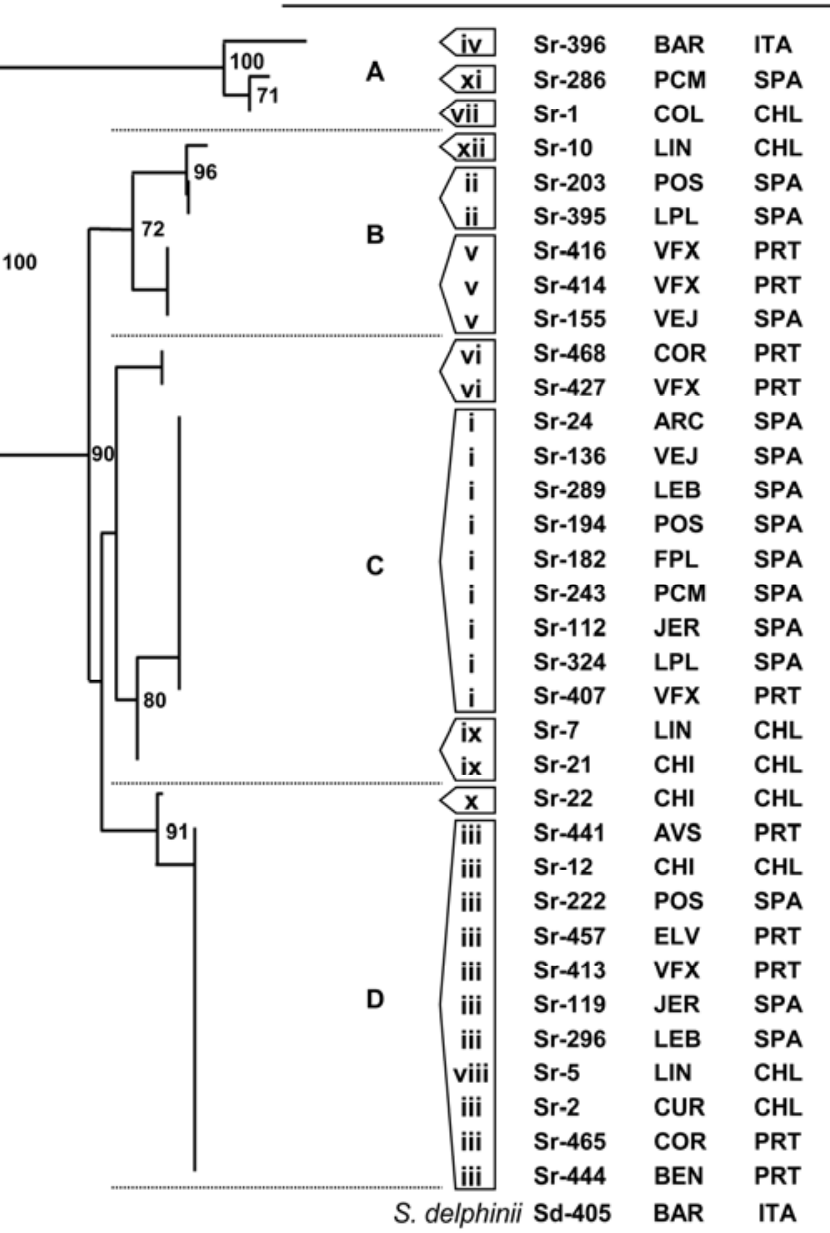

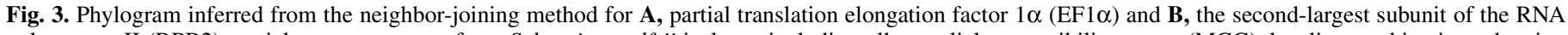

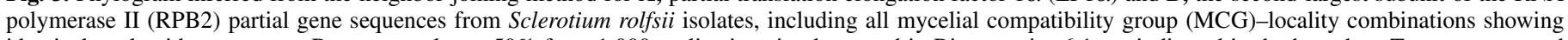

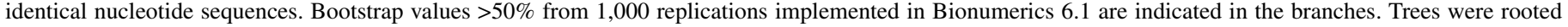

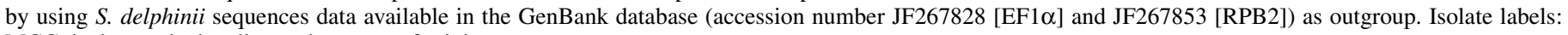
MCG, isolate code, locality, and country of origin. 
ology has been used to advance the understanding of the structure of field populations of this economically important soilborne plant pathogen. In this context, in our study, we used different molecular approaches, including nucleotide sequence analysis from partial single-copy genes and ITS-RFLP analysis, to develop a diagnostic marker system that allowed identification of MCGs of $S$. rolfsii populations infecting sugar beet crops. This approach can provide useful information on the distribution and dispersal of the pathogen.

In our work, we first used ITS-RFLP analysis using four restriction enzymes that identified three different restriction profiles among the 238 S. rolfsii isolates (Table 1; Fig. 1). Based on our ITS-RFLP results, a low degree of variability was estimated among MCGs, with no correlation observed between ITS-RFLP patterns and MCG or geographic origin of the isolates. All isolates belonging to the same MCG showed identical ITS-RFLP patterns. These results are in agreement with those of Nalim et al. (25) that showed that isolates within an MCG had identical MboI ITS-RFLP patterns, concluding that MCGs were predominantly clonal in origin. A higher variability of ITS-RFLP patterns was described by Harlton et al. (14). They found a total of 12 subspecific groups in $67 \mathrm{~S}$. rolfsii isolates from a worldwide collection from different hosts. Some of those groups correlated with their MCG but, in addition, isolates within several MCGs showed different ITS-RFLP patterns and certain patterns were shared among different MCGs. The three ITS-RFLP patterns identified in our study corresponded to ITS-RFLP profiles I, IV, and III described by Harlton et al. (14). Interestingly, those three groups included four isolates that the authors obtained from sugar beet, suggesting certain host specificity.

Although, in our study, the ITS-RFLP analysis did not resolve among the 12 MCGs studied, the combined ITS-RFLP patterns did clearly differentiate the two closely related species $S$. rolfsii and $S$. delphinii. Morphological characteristics such as sclerotial size and optimum growth temperature (31) or specific RAPDs patterns (34) can also be used to distinguish between these two species, although those approaches can be prone to lack of reproducibility.

Considering the total sum of digested band sizes of the ITS amplicon, we noted that M2 and M3 digestion patterns exceeded the size of the undigested PCR-ITS product (Fig. 1). This fact was also noted by Harlton et al. (14), who analyzed two singlebasidiospore strains segregated from a parental strain to resolve it. The ITS-RFLP MboI digest patterns showed two different profiles, indicating two distinct ITS-rDNA sequence types or a heterokaryotic condition in $S$. rolfsii field isolates. Okabe et al. (27) supported such a hypothesis, using protoplasts to determine the types of ITS sequences of homokaryons derived from a single heterokaryon strain. In spite of these studies, the number of total nuclei present in a single hyphal cell in $S$. rolfsii has not been elucidated yet, although cells are multinucleate (32). Consequently, it is not possible to ensure that each ITS-rDNA sequence type corresponds to different nuclei, if it is assumed that those rDNA types could occur in heterokaryotic isolates. Similarly, the presence of multiple copies of the ITS that are not identical may occur in the same monokaryotic individual as has been reported in other fungi $(18,39)$. Recently, Le et al. (20) also found that some isolates of $S$. rolfsii from Vietnam showed polymorphisms in different ITS copies. In our study, two pieces of evidence support the heterokaryotic nature of those MCGs: first, the fact that we obtained a mixture of ITS sequences for a single isolate (although we cannot discard the idea that different copies in the ITS sequence of an isolate may occur in a single nucleus); and second, the fact that all our isolates were monosclerotial and that we found ambiguities in the single-copy genes EF1 $\alpha$ and RPB2 for all MCGs (with the exception of MCG ix). At the present time, the lack of information regarding the number of different nuclei present in a single hyphal cell in $S$. rolfsii MCGs points to the need to identify all sequence types of each heterokaryotic isolate by cloning prior to inferring any detailed phylogenetic relationship among them, which merits future work.

Several single or low-copy nuclear protein-coding genes have been proposed as an alternative to the analysis of nuclear and mitochondrial rDNA genes and have been established as the platform for fungal molecular systematic for the last 20 years $(6,7,15,19)$. Across the phylum Basidiomycota, the EF1 $\alpha$ and RPB2 genes have arisen as suitable molecular markers for intraspecific phylogenetic inference $(4,5,22,24,37)$. However, to our knowledge, the use of those EF1 $\alpha$ and RPB2 sequences in our study represents the first effort for intraspecific variability studies in $S$. rolfsii. These genes have been proven to be useful in our study, either individually or combined, to estimate genetic variability within and between MCGs of $S$. rolfsii and explore their usefulness to detect specific nucleotide polymorphisms that have allowed the identification of those MCGs unequivocally.

Our results showed a direct relationship between the nucleotide sequences for the amplified EF1 $\alpha$ and RPB2 gene regions of each $S$. rolfsii isolate and the MCG identity, with all isolates in the same MCG sharing identical nucleotide sequences (Figs. 2 and 3). The RPB2 gene sequences were more diverse than those of the EF1 $\alpha$ gene, based on variable nucleotide positions. Thus, 10 of the 12 MCGs could be characterized based on the RPB2 region only while the EF1 $\alpha$ region resolved 7 of the 12 MCGs (Fig. 2). These results are in agreement with other studies that concluded that regions of the RPB2 are strongly conserved among eukaryotes $(12,21,24)$ but are more variable than the $\mathrm{EF} 1 \alpha$ in fungi. Interestingly, when the EF1 $\alpha$ and RPB2 sequences were combined, each of the $12 \mathrm{~S}$. rolfsii MCGs included in our study could be resolved unambiguously (Fig. 3). These markers are unlikely to be linked to the geographic origin of isolates but their association with the MCGs was consistently demonstrated. The sequence analysis of representative isolates of these MCGs showed that the distribution and spread of $S$. rolfsii MCGs could be easily monitored by the proposed molecular markers in the present study.

This new diagnostic tool for MCGs in $S$. rolfsii developed in our study might be of great interest because other techniques have allowed the understanding of the epidemiology of diseases caused by other fungal pathogens. Thus, the use of AGs or G. graminis var. tritici groups, together with molecular analyses of the rDNAITS sequences in $R$. solani and G. graminis var. tritici or of VCGs and polymorphisms in a noncoding sequence in $V$. dahliae, have helped to identify genetic subgroups or pathotypes of these pathogens. These subgroups have later been correlated to pathogenicity and virulence and have allowed a description of the spread of these pathogens in different geographical areas $(9-11,16,19)$.

In our study, the distance analysis among $S$. rolfsii isolates based on nucleotide sequences for the specific regions of the EF1 $\alpha$ and RPB2 genes grouped them according to the MCGs, with no correlation with the geographic origin of the isolates. However, based on EF1 $\alpha$ sequences, some correlation existed for MCGs $\mathrm{i}$ and $\mathrm{v}$ present in the same field plot at Vejer de la Fra. and Vila Franca Xira, as well as for MCGs $i$ and xi that were also identified in the same field plot at Paterna del Campo. Similarly, the RPB2 sequence in MCGs iii, viii, and $x$ that were identified in nearby Chilean localities (Table 1) (35) formed well-supported clusters. Interestingly, Remesal et al. (35) previously suggested MCG $\mathrm{i}$ as the original population of $S$. rolfsii in southern Spain, and they suggested that the prevalence of MCG iii, the most widespread group in Portugal and Spain, was likely due to its spread by cultural practices, and that the spread of the pathogen in Chile occurred through several introduction events (35). Our results also suggest that MCG $\mathrm{v}$ and MCGs vii and $\mathrm{x}$ could have originated from MCGs i and iii, respectively.

The applicability and reliability of the combined use of EF1 $\alpha$ and RPB2 genes as a molecular tool for assigning isolates to 
MCGs in $S$. rolfsii was confirmed in blind trials by correctly identifying 25 uncharacterized isolates to their appropriate MCGs using previously typed isolates. The fact that the isolates from India were assigned to a new MCG because these could not be assigned to any of the 12 MCGs described in our previous study (35), either by mycelial pairings or nucleotide sequence, indicates that occurrence of new MCGs could be easily identified in further studies using this new MCG diagnostic tool.

Finally, in this study, we propose a set of tester isolates (Table 1) for MCG identification in $S$. rolfsii based on the assignment of an MCG to specific EF1 $\alpha$ and RPB2 gene sequences that allows the exact characterization and classification of individual isolates into the 12 defined MCGs. This collection of tester isolates will be provided upon request. The excellent resolution achieved by EF1 $\alpha$ and RPB2 gene sequences, and the relatively cheap and ready accessibility of sequencing for most laboratories today, will provide a useful molecular tool to better understand the epidemiology of Sclerotium root rot diseases and monitor the spatiotemporal spread of $S$. rolfsii isolates.

\section{ACKNOWLEDGMENTS}

Financial support for this research was provided by grants AGL200201418 and AGL2005-00751, Ministerio de Educación y Ciencia of Spain and the European Social Fund. E. Remesal was recipient of an FPI fellowship BES-2006-13693 from Ministerio de Educación y Ciencia of Spain. We thank R. Paillalef-Monnrad (IANSAGRO, Chile), M. Paim (ADB, Portugal), and R. Morillo-Velarde (AIMCRA, Spain) for providing Sclerotium root-rot infected root samples for isolation of the pathogen from Chile, Portugal, and Italy, respectively; M. Gutierrez-Sosa (AIMCRA) for helping in the selection of field plots at southern Spain; R. SarabiaZalamea (IAS-CSIC) for excellent technical assistance; and M. G. Milgroom for critically reading the manuscript prior to submission.

\section{LITERATURE CITED}

1. Adandonon, A., Aveling, T. A. S., Merwe, N. A., and Sanders, G. 2005. Genetic variation among Sclerotium rolfsii isolates from Benin and South Africa, determined using mycelial compatibility and ITS rDNA sequence data. Aust. Plant Pathol. 34:19-25.

2. Almeida, A. M. R., Abdelnoor, R. V., Calvo, E. S., Tessnman, D., and Yorinori, J. T. 2001. Genotypic diversity among Brazilian isolates of Sclerotium rolfsii. J. Phytopathol. 149:493-502.

3. Bain, J. M., Tavanti, A., Davidson, A. D., Jacobsen, M. D., Shaw, D., Gow, N. A. R., and Odds, F. C. 2007. Multilocus sequence typing of the pathogenic fungus Aspergillus fumigatus. J. Clin. Microbiol. 45:14691477.

4. Baldauf, S. L. 1999. A search for the origins of animals and fungi: comparing and combining molecular data. Am. Nat. 154:S178-S188.

5. Binder, M., Larsson, K. H., Matheny, P. B., and Hibbett, D. 2010. Amylocorticiales ord. nov. and Jaapiales ord. nov.: Early diverging clades of Agaricomycetidae dominated by corticioid forms. Mycologia 102:865880.

6. Blanz, P. A., and Unseld, M. 1987. Ribosomal RNA as a taxonomic tool in mycology. Pages 247-258 in: The Expanding Realm of Yeast-Like Fungi. G. S. de Hoog, M. T. Smith, and A. C. Weijman, eds. Elsevier, Amsterdam.

7. Bruns, T., White, T., and Taylor, J. 1991. Fungal molecular systematics. Annu. Rev. Ecol. Syst. 22:525-564.

8. Cilliers, A. J., Herselman, L., and Pretorius, Z. A. 2000. Genetic variability within and among mycelial compatibility groups of Sclerotium rolfsii in South Africa. Phytopathology 90:1026-1031.

9. Collado-Romero, M., Mercado-Blanco, J., Olivares-García, C., ValverdeCorredor, A., and Jiménez-Díaz, R. M. 2006. Molecular variability within and among Verticillium dahliae vegetative compatibility groups determined by fluorescent amplified fragment length polymorphism and polymerase chain reaction markers. Phytopathology 96:485-495.

10. Cubeta, M. A., and Vilgalys, R. 1997. Population biology of the Rhizoctonia solani complex. Phytopathology 87:480-484.

11. Daval, S., Lebreton, L., Gazengel, K., Guillerm-Erckelboudt, A. Y., and Sarniguet, A. 2010. Genetic evidence for differentiation of Gaeumannomyces graminis var. tritici into two major groups. Plant Pathol. 59:165178.

12. Denton, A. L., McConaughy, B. L., and Hall, B. D. 1998. Usefulness of RNA polymerase II coding sequences for estimation of green plant phylogeny. Mol. Biol. Evol. 15:1082-1085.
13. Fournier, A., Widmer, F., and Enkerli, J. 2010. Development of a singlenucleotide polymorphism (SNP) assay for genotyping of Pandora neoaphidis. Fungal Biol. 114:498-506.

14. Harlton, C. E., Lévesque, C. A., and Punja, Z. K. 1995. Genetic diversity in Sclerotium (Athelia) rolfsii and related species. Phytopathology 85:1269-1281.

15. Hibbett, D. S. 1992. Ribosomal RNA and fungal systematics. Trans. Mycol. Soc. Jpn. 33:533-556.

16. Jiménez-Díaz, R. M., Olivares-García, C., Landa, B. B., Jiménez-Gasco, M. M., and Navas-Cortés, J. A. 2011. Region-wide analysis of genetic diversity in Verticillium dahliae populations infecting olive in southern Spain and agricultural factors influencing the distribution and prevalence of vegetative compatibility groups and pathotypes. Phytopathology 101:304-315.

17. Kauserud, H., and Schumacher, T. 2001. Outcrossing or inbreeding: DNA markers provide evidence for type of reproductive mode in Phellinus nigrolimitatus (Basidiomycota). Mycol. Res. 105:676-683.

18. Ko, K. S., and Jung, H. S. 2002. Three nonorthologous ITS1 types are present in a polypore fungus Trichaptum abietinum. Mol. Phylogenet. Evol. 23:112-122.

19. Kuninaga, S., Natsuaki, T., Takeuchi, T., and Yokosawa, R. 1997. Sequence variation of the rDNA ITS regions within and between anastomosis groups in Rhizoctonia solani. Curr. Genet. 32:237-243.

20. Le, C. N., Mendes, R., Kruijt, M., and Raaijmakers, J. M. 2012. Genetic and phenotypic diversity of Sclerotium rolfsii in groundnut fields in central Vietnam. Plant Dis. 96:389-397.

21. Liu, Y. J., Whelen, S., and Hall, D. 1999. Phylogenetic relationships among Ascomycetes: Evidence from an RNA polymerase II subunit. Mol. Biol. Evol. 16:1799-1808.

22. Matheny, P. B. 2006. PCR primers to amplify and sequence rpb2 (RNA polymerase II second largest subunit) in the Basidiomycota (Fungi). http://www.clarku.edu/faculty/dhibbett/rpb2primers.htm

23. Matheny, P. B., Curtis, J. M., Hofstetter, V., Aime, M. C., Moncalvo, J. M., Ge, Z. W., Yang, Z. L., Slot, J. C., Ammirati, J. F., Baroni, T. J., Bougher, N. L., Hughes, K. W., Lodge, D. J., Kerrigan, R. W., Seidl, M. T., Aanen, D. K., Matthew, D., Daniele, G. M., Desjardin, D. E., Kropp, B. R., Norvell, L. L., Parker, A., Vellinga, E. C., Vilgalys, R., and Hibbett, D. S. 2006. Major clades of Agaricales: A multilocus phylogenetic overview. Mycologia 98:982-995.

24. Matheny, P. B., Wang, Z., Binder, M., Curtis, J. M., Lim, Y. W., Nilsson, H., Hughes, K. W., Hofstetter, V., Ammirati, J. F., Schoch, C. L., Langer, E., Langer, G., McLaughlin, D. J., Wilson, A. W., Froslev, T., Ge, Z. W., Kerrigan, R. W., Slot, J. C., Yang, Z. L., Baroni, T. J., Fischer, M., Hosaka, K., Matsuura, K., Seidl, M. T., Vauras, J., and Hibbett, D. S. 2007. Contributions of rpb2 and tef1 to the phylogeny of mushrooms and allies (Basidiomycota, Fungi). Mol. Phylogenet. Evol. 43:430-451.

25. Nalim, F. A., Starr, J. L., Woodard, K. E., Segner, S., and Keller, N. P. 1995. Mycelial compatibility groups in Texas peanut field populations of Sclerotium rolfsii. Phytopathology 85:1507-1512.

26. O’Donnell, K., Kistler, H. C., Cigelnik, E., and Ploetz, R. C. 1998. Multiple evolutionary origins of the fungus causing Panama disease of banana: concordant evidence from nuclear and mitochondrial gene genealogies. Proc. Natl. Acad. Sci. USA 95:2044-2049.

27. Okabe, I., Arakawa, M., and Matsumoto, N. 2001. ITS polymorphism within a single strain of Sclerotium rolfsii. Mycoscience 42:107-113.

28. Okabe, I., and Matsumoto, N. 2000. Population structure of Sclerotium rolfsii in peanuts fields. Mycoscience 41:145-148.

29. Okabe, I., Morikawa, C., Matsumoto, N., and Yokoyama, K. 1998. Variation in Sclerotium rolfsii isolates in Japan. Mycoscience 39:399-407.

30. Punja, Z. K. 1985. The biology, ecology and control of Sclerotium rolfsii. Annu. Rev. Phytopathol. 23:97-127.

31. Punja, Z. K., and Damiani, A. 1996. Comparative growth, morphology, and physiology of three Sclerotium species. Mycologia 88:694-706.

32. Punja, Z. K., and Grogan, R. G. 1983. Basidiocarp induction, nuclear condition, variability, and heterokaryon incompatibility in Athelia (Sclerotium) rolfsii. Phytopathology 73:1273-1278.

33. Punja, Z. K., and Grogan, R. G. 1983. Hyphal interactions and antagonism among field isolates and single-basidiospore strains of Athelia (Sclerotium) rolfsii. Phytopathology 73:1279-1284.

34. Punja, Z. K., and Sun, L. J. 2001. Genetic diversity among mycelial compatibility groups of Sclerotium rolfsii and Sclerotium delphinii. Mycol. Res. 105:537-546.

35. Remesal, E., Jordán-Ramírez, R., Jiménez-Díaz, R. M., and NavasCortés, J. A. 2012. Mycelial compatibility groups and pathogenic diversity in Sclerotium rolfsii populations from sugar beet crops in Mediterranean-type climate regions. Plant Pathol. 61:739-753.

36. Remesal, E., and Navas-Cortés, J. A. 2012. An improved growth medium to assess mycelial compatibility groups in Sclerotium rolfsii. J. Phytopathol. 160:237-242.

37. Rodríguez-Estrada, A. E., Jiménez-Gasco, M. M., and Royse, D. J. 2010. 
Pleurotus eryngii species complex: Sequences analysis and phylogeny on partial EF1 $\alpha$ and RPB2 genes. Fungal Biol. 114:421-428.

38. Roger, A. J., Sandblom, O., Doolittle, W. F., and Philippe, H. 1999. An evaluation of elongation factor $1 \mathrm{a}$ as a phylogenetic marker for eukaryotes. Mol. Biol. Evol. 16:218-233.

39. Rooney, A. P., and Ward, T. J. 2005. Evolution of a large Ribosomal RNA multigene family in filamentous fungi: Birth and death of concerted evolution paradigm. Proc. Natl. Acad. Sci. USA 102:5084-5089.

40. Saitou, N., and Nei, M. 1987. The neighbor-joining method: A new method for reconstructing phylogenetic trees. Mol. Biol. Evol. 4:406-425.

41. Tanabe, Y., Saikawa, M., Watanabe, M. M., and Sugiyama, J. 2004. Molecular phylogeny of Zygomycota based on EF-1a and RPB1 sequences:
Limitations and utility of alternative markers to rDNA. Mol. Phylogenet. Evol. 30:438-449.

42. Wendland, J., and Kothe, E. 1997. Isolation of tef1 encoding translation elongation factor EF-1a from the homobasidiomycete Schizophyllum commune. Mycol. Res. 101:798-802.

43. White, T. J., Bruns, T., Lee, S., and Taylor, J. 1990. Amplification and direct sequencing of fungal ribosomal RNA genes for phylogenetics. Pages 315-322 in: PCR Protocols: A Guide to Methods and Applications. M. A. Innis, D. H. Getfand, J. J. Sninsky, and T. J. White, eds. Academic Press, San Diego, CA.

44. Worrall, J. J. 1997. Somatic incompatibility in basidiomycetes. Mycologia 89:24-36. 